\title{
SEGREGATION BY RACE IN PUBLIC SCHOOLS RETROSPECT AND PROSPECT
}

\author{
ARThUR E. SUTHERLAND*
}

I

The problem of this paper has many aspects. A sociologist might consider it as a study of changing attitudes of large groups of people, varying in time and place. A practical politician who thought of it in much the same way would certainly describe it in different words. A school administrator might treat it as a study of efficient pedagogy. The American lawyer, no matter whether he comes from a northern or southern state, ${ }^{1}$ is apt to consider it as a problem in federalism. He may

* Professor of Law, Harvard Law School.

1 "The South" is not an exact term. Harry S. Ashmore, in The Negro and the Schools 13 note, (1954), includes in it I3 states-Alabama, Arkansas, Florida, Georgia, Kentucky, Louisiana, Mississippi, North Carolina, Oklahoma, South Carolina, Tennessee, Texas, and Virginia. All these states require that Negroes and whites be educated separately. But so do (or did before the Supreme Court decisions of May, 1954) Delaware, Maryland, Missouri, and West Virginia. So did the District of Columbia. And in Arizona, Kansas, New Mexico, and Wyoming, segregated schooling was optional, though there is no record of its being practiced in Wyoming. The constitutional and statutory references covering all these $2 x$ states, the District of Columbia, and Alaska, are given below in this note.

In Florida, Kentucky, Oklahoma, and Tennessee schooling whites and Negroes together is expressly forbidden by statute even in private schools (Fra. Stat. AnN. \$228.09 (I953); Ky. Rev. Stat. AnN. \$158.020 (1953); OKLA. STAT. tit. 70, \$5-5; TENN. CODE ANN. \$II395 (Williams I934)).

Some states make special provision for peoples other than Negroes and whites. Delaware directs the establishment of schools for "children of people called Moors or Indians" (DeL. Code ANN. tit. x4, \$I4I(c) (x953)). Mississippi and North Carolina make separate provision for Indians (Miss. Code ANN. $\$ 6632$ (1942); N. C. CoDE $\$ 115-2$ (1943)). In New York, Indian children on reservations changed from separate schools to the general public school system in September, 1954. See N. Y. Times, Sept. 29, I954, p. I, col. 7 .

In Mississippi, "white" means "Caucasian"; "colored" means all other races (Gong Lum v. Rice, 275 U. S. 78 (1927)). In Oklahoma, "colored children" means children of African descent. "White children" includes all others (OkzA. Const. Art. XIII \$3).

In Alaska, the legislature is empowered "to establish and maintain schools for white and colored children and children of mixed blood who lead a civilized life in said Territory. . .." (Alasks Comp. Laws ANN. \$37-I-X (1949)), but this appears to be construed not to provide for segregated schools (Jones v. Ellis, 8 Alaska $146, x_{47}($ (1929)).

Segregation Mandatory

Constitutional and Statutory References

Alabama: Alabama Const. Art. XIV, \$256.

ALA. CODE tit. 52, $\$ \$ 93$, I67 (1940).

Arkansas: ARk Stat. Anno. $\$ 80-509$ (1947).

Delawvare: Dex. Const. Art. ro, \$2.

Del. Code Ann. tit. I4, \$I II (1953).

District of Columbia: D. C. CODE ANN. \$\$3I-IIIO, 3I-IIII, 3I-III3, 3I-IOII (195I).

Florida: Fla. Const. Art. I2, \$I2.

FLA. Stat. ANn. \$228.09 (1953).

Georgia: GA. Const. Art. VIII, \$2-640I.

GA. Code ANN. $\$ \$ 32-909,32-937$ (1952).

Kentucky: Ky. Const. $\$ 187$.

KY. Rev. StAT. ANn. $\$ \$ 158.020,158.021,158.025$ (1953).

Lonisiana: LA. Const. Art. XII, \$1. 
ask how far the government of the United States will undertake to oblige the inhabitants of a minority of the states of the union to comply with what the constitutional organs of that government declare to be proper in public education, and what practical means of enforcement and resistance the legal mechanisms of the nation and states provide.

On May I7, 1954, the Supreme Court of the United States, deciding the substantive issues in five notable cases, ${ }^{2}$ indicated that hereafter the Federal Government would require of all public schools compliance with a new standard of equal treatment of pupils, regardless of race, a standard under which separate education of Negroes and whites is proscribed. This paper will treat of that decision, and some of its possible effects.

A surprise awaiting one who first begins the study of racial segregation in public schools is the legal persistence of the practice in some Northern areas until comparatively recent times. Charles Sumner's eloquent but unsuccessful argument made a little over a century ago on behalf of Sarah Roberts, a Negro child, in her attempt to gain admission to a Boston school for white children, is an early landmark. ${ }^{8}$ The segregation upheld in that case was eliminated by a Massachusetts statute in I855, but today's Northerner is apt to learn with some amazement that the New

Maryland: MD. ANN. Code Gen. LAws Art. 77, $\$ 124,207$ (1951).

Mississippi: Miss Const. Art. 8, \$207.

Mrss. Code Ann. $\$ \$ 6276,6632,6633$ (r942).

Missouri: Mo. Const. Art. XI, \$I(a).

Mo. REv. StAT. $\$$ I63.I30 (I949).

North Carolina: N. C. Consr. Art. 9, \$2.

N. C. CODE §II5-2 (I943).

Oklahoma: OkLA. Const. Art. I, \$5, Art. XIII, \$3.

OkIA. STAT. tit. 70, \$\$5-I, 5-5 (195I).

Okla. Laws of 1949, p. $608, \$$ I.

South Carolina: S. C. ConsT. Art. II, \$7.

S. C. CODE \$2I-75I (I952).

Tennessee: Tenn. Const. Art. II, \$12.

Tenn. Code AnN. $\$ \$ 2377,2393.9$ (Williams 1934).

Texas: Tex. Const. Art. $7, \$ 7$.

Tex. Stat., Rev. Civ. Art. 2900 (I948).

Virginia: VA. Const. Art. 9, §I 40.

VA. CODE \$29-22I (I950).

West Virginia: W. VA. CoNst. Art. 12, $\$ 8$.

W. VA. CODE ANN. $\$ \$ 7775$, I894 (1949).

Segregation Optional

Arizona: ARJz. CODE ANN. \$54-4I6 (Supp. 1952).

Kansas: Kan. Gen. STAT. $\$ \$ 21-2424,72-1724$ (1949).

New Mexico: N. M. STAT. ANN. \$55-1201 (1941).

Wyoming: Wro. Const. Art. 7, \$ro.

Wyo. CoMp. Stat. Ans. \$67-624 (1945).

${ }^{2}$ Brown v. Board of Education of Topeka, Shawnee County, Kansas; Briggs v. Elliott; Davis v. County School Board of Prince Edward County, Virginia; Gebhart v. Belton; reported in 347 U.S. 483 (1954), arose respectively in Kansas, South Carolina, Virginia, and Delaware. All except the Delaware case originated in federal courts. In the Delaware case alone the plaintiff Negroes had prevailed in the lower court.

The District of Columbia case is Bolling v. Sharpe, 347 U.S. 497 (1954).

${ }^{3}$ Roberts v. Boston, 5 Cush. I98 (Mass. I849); rule reversed by Mass. Acts 1855, c. 256. 
York Court of Appeals upheld segregation in the Brooklyn public schools in Igoo, and the Indiana Supreme Court reached the same result concerning Indianapolis schools in $1926{ }^{4}$ Less than three months after the decision of the New York case, its rule was reversed by a statute which provided ${ }^{5}$

No person shall be refused admission into or be excluded from any public school in the state of New York on account of race or color.

New York has gone farther than this prescription for public schools: it has imposed its statutory policy against discrimination by race on at least some private schools. ${ }^{6}$ The statutes of a few other states contain somewhat similar provisions. ${ }^{7}$

The states of the nation could be divided into four classes, according to their treatment of Negroes or other racial groups in education. In I7 states and in the District of Columbia, prior to the seventeenth of May, I954, segregation of Negro students from others in publicly maintained schools was mandatory by constitution or by statute. In 4 other states segregation was optional though not required. In the remaining 27 states, segregation in the public schools is prohibited, or there is no legislation on the subject. In a few of these states, segregation by race even in private institutions is prohibited. ${ }^{8}$ In this federal republic of 48 states, then, the organic law of the whole is in process of enforcement against the inconsistent law of 2I, and against whatever inconsistent federal statutes may apply to a federal area. The very bulk of the dissenting states makes this a particularly troublesome problem of nationstate relations.

II

The Fourteenth Amendment makes no mention of schools. Its general clauses which might bear on segregated state schooling are three: that which forbids the state to make or enforce any law which shall abridge the privileges or immunities of citizens of the United States; that which forbids a state to deprive any person of life, liberty or property without due process of law; and that which forbids a state to deny to any person within its jurisdiction the equal protection of the laws. The phrase

\footnotetext{
- People ex rel. Cisco v. School Board, I6r N.Y. 598, 56 N.E. 8x (rgoo). And see Greathouse v. Board of Sehool Commissioners of Indianapolis, I98 Ind. 95, I5I N.E. 4II (1926); result reversed by IND. ANN. StAт. \$28-5160 (I953 Cum. Supp.). In Hillsboro, Ohio, parents of Negro children sought an injunction against racial segregation in public schools, in September 1954. See N.Y. Times, Sept. 30 , 1954, p. 32 , col. 4 .

NN.Y. Laws of igoo, c. 492.

'N.Y. Civil Rights LAw, $\$ 40$. The institutions covered include “. . public libraries, kindergartens, primary and secondary schools, high schools, academies, colleges and universities, extension courses, and all educational institutions under the supervision of the regents of the state of New York; and any such public library, kindergarten, primary and secondary school, academy, college, university, professional school, extension course, or other educational facility, supported in whole or in part by public funds or by contributions solicited from the general public. ..." See McKaine v. Drake Business School, 107 Misc. 24I, ז76 N.Y. Supp. 33 (Sup. Ct. r9r9).

${ }^{7}$ New lersey: N.J. Stat. ANN. \$10:1-5 (1939).

Pennsylvania: PA. Stat. ANw. tit. I8, $\$ 4654$ (1945).

Washington: WASH. REv. CODE \$9.9x.oro (I953).

Massachusetts: Mass. Gen. Laws c. 272, \$92A (r953 Cum. Supp.).

${ }^{8}$ See the summary and tabulation in notes $I$ and 7 , stipra.
} 
"privileges and immunities of citizens of the United States" was so narrowly construed in 1873 in the Slaughterhouse Cases $^{9}$ that it lost any meaning helpful in the school question. There remain therefore of the Fourteenth Amendment clauses only the two concerning due process and equal protection. Efforts to end segregation in the public schools of the states have turned on the equal protection clause which appears much more immediately relevant and less vague than "due process of law."

The history of segregation in public or publicly controlled institutions since the adoption of the Fourteenth Amendment has had three phases. In 1896 came a determination that equal protection was given by giving equal facilities, even if these facilities were prescribed separately for different racial groups. ${ }^{10}$ Relatively recently came multiple litigation in which the states, availing themselves of the privilege to furnish separate but equal facilities, found the equality in fact of these facilities subject to determination by the federal courts. ${ }^{11}$ The third stage began with the decisions of May I7, 1954, which held segregation in public schools a denial of the equal protection of the laws by states, without regard to equality in the separate facilities; and found segregation a denial of due process by the United States in the District of Columbia. This third stage will apparently continue as long as the federal courts are called on to decide whether the allotment of pupils to public schools is in fact made for reasons other than race.

"Equal but separate" had its Supreme Court origin in 1896 in Plessy v. Ferguson (supra note ro) although there had been antecedent decisions in state courts, and federal legislation in the District of Columbia had indicated that the Congress (if it thought of the matter) did not deem separate schools for Negroes inconsistent with any constitutional provision. Plessy's case arose out of an intrastate railroad journey in Louisiana. Plessy, one-eighth Negro, was convicted in a Louisiana state court for the statutory offense of riding in a coach reserved for whites. When he brought his case to the Supreme Court of the United States, that Court held that so long as Louisiana by statute required that facilities afforded Negroes be equal to those provided for whites, compulsory separation was no violation of the Fourteenth Amendment. The Court's opinion was not unanimous. Associate Justice Harlan, dissenting, spoke not only of the Fourteenth Amendment but of the Thirteenth, reasoning that when the Constitution was amended to forbid slavery, the amenders intended to eliminate all that went with slavery, and that legal segregation of the one-time slave race was a relic of its servile status. ${ }^{12}$

${ }^{\circ} \mathrm{x} 6$ Wall. 36 (U.S. 1873 ).

${ }^{10}$ Plessy v. Ferguson, I63 U.S. 537 (1896).

${ }^{11}$ Corbin v. County School Board, Pulaski County, Va., I77 F.2d 924 (4th Cir. 1949); Carter v. School Board of Arlington County, Va., 182 F.2d 531 (4th Cir. 1950); Brown v. Ramsay, 185 F.2d 225 (8th Cir. I950) (Ark.); Winborne v. Taylor, r95 F.2d 649 (4th Cir. I952) (N.C.); McSwain v. County Board of Education, to4 F. Supp. 86x (E.D. Tenn. 1952); Wichita Falls Junior College District v. Battle, 204 F.2d 632 (5th Cir. 1953) (Tex.). See Robert A. Leflar and Wylie H. Davis, Segregation in the Prblic Schools-1953, 67 Harv. L. Rev. 377, 392 et seq. (1954) for other examples.

${ }_{12}{ }_{1} 63$ U.S. 537 ( 1896$)$. In his opinion in Brown v. Board of Education of Topeka, 347 U.S. 843 (1954), Mr. Chief Justice Warren stated that the doctrine of "separate but equal," enunciated in Plessy, had since then come before the Supreme Court in only six education cases. The first of these was Cum. 
In I927 the Supreme Court applied the principle of "equal but separate" to public schools. ${ }^{13}$ The Mississippi Constitution of 189o provided in Section 207:

Separate schools shall be maintained for children of the white and colored races.

Martha Lum, a nine-year old child of Chinese descent, born in the United States, was excluded from a Mississippi school for white children on the ground that she was not a member of the white race. Her father Gong Lum, and a "next friend" obtained a mandamus order in a lower Mississippi court to compel the school authorities to admit Martha to the white school. But the Supreme Court of Mississippi reversed this decision, and the Supreme Court of the United States, in an opinion by Mr. Chief Justice Taft, unanimously affirmed the judgment of the Supreme Court of Mississippi, citing Roberts v. Boston (supra note 3), Plessy v. Ferguson, and the statutes passed by the Congress concerning segregated schools in the District of Columbia.

During the next seventeen years the Supreme Court and the lower federal courts; accepting "equal but separate," were required in a number of cases to decide whether or not equality actually existed in public educational facilities. The cases which reached the Supreme Court all involved university study. That equality in fact was a condition of permissible separateness appeared in 1938, when Missouri failed in an effort to demonstrate equal treatment of Negro law students by offering them tuition scholarships to study in other states. ${ }^{14}$ The state maintained a school of law, to which only white students were admitted. One Lloyd Gaines, unsuccessful in obtaining a writ of mandamus from the Missouri state courts against the officers, regents, Registrar, and Curators of the University of Missouri to compel his admission to the white law school, obtained a reversal in the Supreme Court of the United States. That Court thus eliminated the possibility that any state could escape the expense of maintaining duplicate facilities for Negroes by offering, to the occasional Negro candidate who might wish to accept, tuition at out-of-state institutions.

In $195^{\circ}$ the Supreme Court decided two more significant cases concerning higher education. One of these, involving the comparative merits of Negro and white law

\footnotetext{
ming v. County Board of Education, I75 U.S. 528 (1899), in which colored citizens of Georgia failed in an action to enjoin the Board of Education of Richmond County from maintaining a high school for white children without also maintaining one for colored pupils. The opinion was written for a unanimous court by Mr. Justice Harlan, who had dissented in Plessy. He pointed out that the relief asked was an injunction that would have either impaired the efficiency of the white high school or compelled its closing, thus taking away education from white without giving it to colored children; and that if in some appropriate proceeding for the purpose, the plaintiffs had sought to compel the Board of Education to cstablish a high school for colored children, and if it appeared that the Board's refusal to maintain such a school was an abuse of discretion, different questions might have arisen. Mr. Justice Harlan seems to suggest that Cumming goes off on the wrong choice of remedy, and that "equal but separate" is only remotely involved. The second and third of the six cases, were Gong Lum v. Rice, 275 U.S. 78 (1927) and Missouri ex rel. Gaines v. Canada, 305 U.S. 337 (1938), discussed at page I73 of this article. In the fourth case, Sipuel v. University of Oklahoma, 332 U.S. 63 I (I948), a Negro applicant was granted a writ of mandamus for admission to the University of Oklahoma School of Law, which had been limited to white students; the fifth and sixth were Sweatt v. Painter, 339 U.S. 629 (1950) and McLaurin v. Oklahoma State Regents, 339 U.S. 637 (I950), both of which are discussed at page I74 of this article.

${ }^{13}$ Gong Lum v. Rice, 275 U.S. 78 (1927).

14 Missouri ex rel. Gaines v. Canada, 305 U.S. 337 (1938).
} 
schools in Texas, made it clear that actual equality of academic facilities of every sort was necessary to satisfy the requirement of equal protection. ${ }^{16}$ On the same day the Court held that the University of Oklahoma denied equal protection of the laws of that state to a Negro graduate student named McLaurin by requiring him to occupy a specified classroom seat in a row reserved for colored students, a separate table for colored students in the library, and a separate table in the cafeteria. ${ }^{10}$ Even though he thus attended the same instruction, had access to the same books, and ate the same food as the white students, the Supreme Court said he was denied equal protection. Mr. Chief Justice Vinson wrote of the restrictions which the Court found invalid (339 U.S. at $64 \mathrm{I}$ ):

... they signify that the State, in administering the facilities it affords for professional and graduate study, sets McLaurin apart from the other students. The result is that appellant is handicapped in his pursuit of effective graduate instruction. Such restrictions impair and inhibit his ability to study, to engage in discussions and exchange views with other students, and, in general, to learn his profession.

By the end of 1950 , the Supreme Court had thus made it clear that if segregated schooling was to be tolerated at all, the equality in question could not be merely nominal. In the meantime, in various cases in lower federal courts, judges were examining the comparative facilities in grade and high schools available to Negroes and whites, and were enforcing substantial equivalence by injunctive process. ${ }^{17}$ In such opinions one finds judges weighing comparative "Carnegie Units," ${ }^{18}$ professional certificates held by teachers, accreditation by the "Southern Association," character of school buses, length of school bus journeys, breadth of curriculum, athletic and other physical education facilities, auditorium space available, summer school facilities, extra-curricular activities, and similar features. "Equal but separate" obliged the federal judges not only to compare the relative sufficiency of school facilities, but to scrutinize the diligence of local school boards in correcting inequalities where these existed. If the local school authorities were, in the opinion of the federal courts, making reasonable efforts to correct inequalities, Negro plaintiffs were denied mandatory admission to white schools.

Before the seventeenth of May, I954, then, the Supreme Court continued to restate the theory that states might constitutionally afford equal but separate educational facilities for Negro and white students; but the application of this principle to state universities was such as to make furnishing equal facilities practically impossible; and on the grade and high school level, federal district courts and courts of appeal were strict in applying the requirement of substantial equality, though recognizing that complete and exact equality was a practical impossibility and exhibiting some tolerance of the inevitable delays in what seems to have been a major program in the

${ }^{15}$ Sweatt v. Painter, 339 U.S. 629 (1950).

${ }^{10}$ McLaurin v. Oklahoma State Regents, 339 U.S. 637 (1950).

${ }^{17}$ A selection of such cases is given in note $\mathrm{II}$, stupra. An admirable analysis is found in Robert H. Leflar and Wylie H. Davis, Segregation in the Public Schools-1953, 67 Harv. L. Rev. 377 (1954). schools. 
South to stave off desegregation by achieving actual separate equality in Negro schools.

On May 17, I954, the Supreme Court, in its two short and unanimous opinions, ${ }^{19}$ abolished the doctrine of "equal but separate" public education. The first of these opinions announced the unconstitutionality of segregated schools in Kansas, South Carolina, Virginia, and Delaware. The second found school segregation similarly unconstitutional in the District of Columbia. In all five cases the Court held that segregation according to race in public schools was a violation of constitutional prohibitions-of the Fourteenth Amendment in the state cases and of the Fifth as regards the District of Columbia.

The opinion in the four state cases, after giving the facts, disclaimed any idea that by a sufficiently close study of the circumstances surrounding the adoption of the Fourteenth Amendment a court could find some instruction, sufficiently clear for reliance, as to whether the Fourteenth Amendment permitted or forbade segregated public education. Chief Justice Warren's opinion was frank about the inconclusive nature of this historical study. He said (347 U.S. at 489):

This discussion and our own investigation convince us that, although these sources gave some light, it is not enough to resolve the problem with which we are faced. At best, they are inconclusive.

This inconclusive character was accentuated by the rudimentary nature of public education in some parts of the United States in I868. The Court pointed out that in the South the movement toward free common schools supported by general taxation had then gained little headway. Even in the North ungraded schools were common in rural areas, and compulsory attendance, the Court said, was virtually unknown. Under these circumstances, it is not surprising to find that the various groups drafting and ratifying the Fourteenth Amendment did not clearly have before them the problems facing the contemporary United States, in which compulsory schooling is everywhere accepted as normal, and in which increasingly elaborate school establishments acutely point up any favoritism in their administration.

In the previous equal but separate education cases before the Court, the unanimous opinion argues, it was unnecessary to consider overturning Plessy v. Ferguson; either the issue was not properly raised, or inequality in the schools was evident, and thus the Court was not faced with a case where mere segregation, without tangible inequality, was under consideration. Reconciliation of later with prior decisions in order to preserve the decorum of judicial continuity is an accepted and useful convention. No good purpose is here served by speculating on the soundness of this statement that McLaurin of $195^{\circ}$ was a case substantially different from the five grade school cases of May, 1954. At any rate the Court found that, in the four cases then decided, the Negro and white schools below had been equalized, or were "being equalized" with respect to buildings, curricula, qualifications, salaries of

${ }^{10}$ Brown v. Board of Education of Topeka, and other cases, 347 U.S. 483 (1954); Bolling v. Sharpe, 347 U.S. 497 (1954). Sce note 2, supra. 
teachers, and other tangible factors. In these cases, then, the Court was faced with a decision as to the effect on public education of segregation by itself.

The opinion in the four state cases rejects the verbal symmetry of the argument that if equal tangible facilities be available alike for the Negro child and the white child, the state is granting equal protection though the two be kept separate, and thus the Negro is no more prejudiced than the white. To say that the state awakens in the white child who is forbidden to go to a Negro school the same feelings that it generates in the Negro who is forbidden to go to the white school, is to disregard the entire history of negro slavery and its consequences since 1865 . The Court recognizes this difference in the effect on Negro children (347 U.S. at 494-495):

To separate them from others of similar age and qualifications solely because of their race generates a feeling of inferiority as to their status in the community that may affect their hearts and minds in a way unlikely ever to be undone. The effect of this separation on their education opportunities was well stated by a finding in the Kansas case by a court which nevertheless felt compelled to rule against the negro plaintiffs:

"Segregation of white and colored children in public schools has a detrimental effect upon the colored children. The impact is greater when it has the sanction of the law; for the policy of separating the races is usually interpreted as denoting the inferiority of the negro group. A sense of inferiority affects the motivation of a child to learn. Segregation with the sanction of law, therefore, has a tendency to [retard] the educational and mental development of negro children and to deprive them of some of the benfits they would receive in a racial [ly] integrated school system."

Whatever may have been the extent of psychological knowledge at the time of Plessy v. Ferguson, this finding is amply supported by modern authority. Any language in Plessy v. Ferguson contrary to this finding is rejected.

We conclude that in the field of public education the doctrine of "separate but equal" has no place....

It is always a little surprising to remind one's self that the Constitution contains no express requirement that the Federal Government give its people equal protection. The Supreme Court found it unnecessary in the four state cases to consider whether segregation violated the due process clause of the Fourteenth Amendment; but in the District of Columbia case, the due process clause of the Fifth Amendment was the only provision available. The Court of Appeals of the District of Columbia, by divided vote, had declined to enjoin segregation in the district in $1950^{20}$ and the lower federal courts ruled similarly in Bolling v. Sharpe. But the Supreme Court, reversing the decision below, declared segregated schooling a denial by the United States of due process of law. Chief Justice Warren, speaking for the unanimous Court, laid a broad philosophic foundation for the decision. He stated a concept of government limited to action for reasonable ends (347 U.S. at 499-500):

Although the Court has not assumed, to define "liberty" with any great precision, that term is not confined to mere freedom from bodily restraint. Liberty under law extends to the full range of conduct which the individual is free to pursue, and it cannot be restricted except for a proper governmental objective. Segregation in public education is

${ }^{20}$ Carr v. Corning, Superintendent of Public Schools, I82 F.2d 4 $_{4}$ (D.C. Cir. 1950). 
not reasonably related to any proper governmental objective, and thus it imposes on Negro children of the District of Columbia a burden that constitutes an arbitrary deprivation of their liberty in violation of the the Due Process Clause.

These are words in a great tradition, a tradition sometimes forgotten or doubted in a time when we must constantly turn to government for innumerable services and prohibitions. They are a reminder that despite the constricting of individual man by the crowd, escape from harassment remains a great good; they give off an echo of Locke, choosing, significantly, to write "Of the Extent of the Legislative Power," and telling us ${ }^{21}$

... that even absolute Power, where it is necessary, ... is still limited by that Reason, and confined to those Ends, which required it. ...

At the end of its opinions the Court, expanding the conventional "settle decree on notice," directed in all five cases reargument of two questions at the October, I954 term. The Court first asks for light as to whether within "normal geographic school districting" Negro children must forthwith be admitted to schools of their choice; or, on the other hand, whether the Supreme Court of the United States, in the exercise of its equity powers, might permit effective gradual adjustment from segregated systems to a system not based on color distinctions. Assuming that such a gradual adjustment is decided upon, the Court in the second place asks whether it should formulate the decrees and, if so, what they should contain: whether the Court should appoint a Master to take evidence on the terms of the decree; or whether the Court should remand the cases to the courts of first instance for decrees to be formulated there.

As this paper is written, in October, 1954, the result of the required reargument is necessarily a matter of speculation. One might hazard the suggestion that settlement of the terms of final decrees is work for trial courts; that gradual desegregation is constitutionally permissible if there be some educational or administrative reason for it aside from racial prejudice alone; that delay solely to allow reluctant parents to grow used to the approaching inevitable is forbidden by the Constitution. But this remains to be seen.

III

The effect of the segregation cases on the people of the United States, like the effect of all new law, whether made by legislatures or by judges, is not easy to predict. One can speculate about the profound influence on a whole new generation of equal association in the classroom and, wondering about a new era in social relations, reflect that, even in states where such classrooms have long been common, traces of race troubles can still be seen. A more immediate inquiry concerns the legal effectiveness of the Supreme Court's judgment in the states where it runs counter to present practice. The $2 I$ affected states and the District of Columbia

\footnotetext{
${ }^{21}$ John Locke, Of Civil Government, Book II, An Essay Concerning the Troe Orsginal, Extent AND END of CIviL Government c. XI, Of the Extent of the Legislative Power, par. I39, p. 188 (Everyman's Lib., Rhys ed. 1924).
} 
present a moving picture, confused by the rapid change of scenes. There is a succession of state commissions, legislative proposals, constitutional amendments, headlines, feature articles, and gubernatorial pronouncements which sometimes seem related to the fact that public schools and political campaigns open at about the same time. For the moment the whole subject seems more journalism than constitutionalism, fluid as law, but notably conspicuous as a contemporary problem.

In the District of Columbia and in 7 states, integration of schools appears to have been accepted as a decided matter, ${ }^{22}$ and as classes open in the fall of 954 the authorities, with somewhat varying alacrity, are proceeding to make it effective. The movement to carry out the Supreme Court's judgment in good heart was greatly advanced by President Eisenhower when, on the day after the decisions were handed down, he told the Commissioners of the District of Columbia that he hoped the national capital would be a model for other areas that had changeover problems because of the Supreme Court's ruling, and asked the Commissioners for regular reports on their progress in ending school segregation. ${ }^{23}$ Hobart M. Corning, Superintendent of Schools, immediately began arrangements for the change, to begin in the fall of $\mathrm{I} 954$ and to be substantially completed by the fall of $\mathrm{I} 955$. The plan was adopted by the Board of Education despite the contrary vote of two Negro members who; understandably enough, urged that the changeover be handled at once. ${ }^{24}$ But the plan was, on the other hand, too rapid to suit a group called the Federation of Citizens : Associations, which in September attempted to enjoin effective desegregation.in the District of Columbia until the Supreme Court should have decreed a "'master plan' for the Nation." Federal District Judge Schweinhaut on September 9 denied the injunction, after hearing argument from the Assistant Corporation Counsel of the District who pointed out that desegregation was already far advanced, great expense had been incurred in the process, and that reversal at this point would be costly and chaotic for the schools of the District. ${ }^{25}$

The most notable feature of the commencement of desegregation was its generally calm reception. A somewhat unusual preacher in Hobbs, New Mexico, declaring that God had segregated the three children of Noah, organized a Segregation Committee to protest the change, but the schools in Hobbs quietly opened with mixed attendance despite his biblical warning. ${ }^{26}$ In Philippi, West Virginia, two hundred angry white parents crowded the School Board's meeting room to protest the assignment of a white teacher and a dozen white students to what had been an all-Negro school, and members of nine white families announced that they would not send their children to such an establishment. ${ }^{27}$

${ }^{22}$ N.Y. Times, Sept. 12, 1954, $\$ 4$, p. $2 E$, col. 3. Full compliance was reported in the optional states of Arizona, New Mexico, and Kansas. There were no segregated schools in the fourth optional state, Wyoming. Four border states-West Virginia, Maryland, Missouri, and Delaware-as well as the District of Columbia, had begun integration in at least some of their schools.

${ }^{23}$ N.Y. Times, May $x 9$, 1954, p. I, col. 4. ${ }_{24}$ N.Y. Times, June 3, 1954 p. 25, col. 4.

${ }^{25}$ N.Y. Times, Sept. I0, 1954, p. I, col. 5. $\quad{ }^{26}$ N.Y. Times, Aug. 31, 1954, p. r, col. 3.

${ }^{27}$ N.Y. Times, Aug. 19, x954, p. 2x, col. 2. A "strike" of pupils in another West Virginia high school at White Sulphur Springs was reported on Sept. 13, 1954. See N.Y. Times, Sept. 14, 1954, p. 23, cols. 3 and 4. 
In the community known as "Four States" in Marion County, West Virginia, a state court injunction was used to end the "rebellion" of 53 parents who as a protest kept their children out of an integrated school..$^{2 \pi^{2}}$

Integration in Delaware began calmly, and except in a few communities continued uneventfully. In the small city of Milford, however, due apparently to the efforts of one Bryant W. Bowles, leader of the "National Association for the Advancement of White People," there occurred some disorder and picketing of a formerly white high school to which ten Negroes had been admitted. The School Board resigned, and the successor board resolved the crisis by sending the ten Negroes to a school some I7 miles away. ${ }^{27 b}$ On October I4, 195I, Vice Chancellor Marvel of the Delaware Chancery Court, on the application of the parents of the ten excluded children, held that the children were entitled to injunctive relief readmitting them to the Milford school. ${ }^{27 c}$ The school board served a notice of appeal, and the enforcement of the decree was stayed by the state Supreme Court until the middle of December. ${ }^{2{ }^{d}}$ It was notable that in Wilmington, the largest city of Delaware, and in the small town of Dover, only twenty miles from Milford, desegregation occurred without disorder or complication.

Unruly protests similar to those which had appeared in Delaware made brief appearances in Baltimore and Washington. Baltimore Police Commissioner Ober declared that he would enforce regulations making it illegal to persuade children to stay out of school; in Washington, Superintendent of Schools Corning warned "strikers" that they would disqualify themselves for all school privileges and be denied extra-curricular activities. The disturbances in Baltimore and and Washington immediately came to an end. ${ }^{20}$ The most striking feature of such episodes in the press was their comparative rarity.

In North Carolina, an Associated Press survey on September 4, I954 reported that no Negroes had applied for admission to white schools. ${ }^{28}$ With 8 other states, North Carolina appeared to be taking a wait-and-see attitude, delaying action until the Supreme Court should have taken further steps. ${ }^{29}$ Four states in the deep SouthGeorgia, Louisiana, Mississippi, and South Carolina-were making such moves as seemed possible to avoid the expected decree by legal strategem. ${ }^{30}$ Even in this region, where for various reasons the strongest resistance might be expected, there was little talk of forcible opposition. The legal maneuvers reflected the perennial

27a N.Y. Times, Sept. 30, 1954, p. 32, col. 2.

${ }^{27 \mathrm{~b}}$ Id., col. I.

${ }^{2 r c}$ N.Y. Times, Oct. 15, 1954, p. x, col. 6 .

${ }^{270}$ Simmons v. Steiner, 23 U.S.L. WEEK $2 \times 88$. See for a review of the Milford case, N.Y. Times, Oct. $24,1954, \S e$, p. 4 , col. I.

s7o See Time, Oct. 18 , I954, p. 50; id., Oct. 25, 1954, p. 43. A continuing survey of the effect of the decisions of the Supreme Court of the United States of May 17, 1954, is being made by the Southern School News published by the Southern Educational Reporting Service, Nashville, Tennessee.

${ }^{28}$ N.Y. Times, Sept. 5, x954, p. 36 , cols. I and 2.

${ }^{20}$ N.Y. Times, Sept. 12, $2954, \$ 4$, p. $2 \mathrm{E}$, col. 3. The nine "wait and see" states were: Arkansas, Alabama, Florida, Kentucky, North Carolina, Oklahoma, Tennessee, Texas and Virginia.

${ }^{30}$ N.Y. Times, Sept. 12, 1954, \$4, p. $2 E$, col. 4 . 
and generally vain hope of those to whom some law is displeasing that by a change in verbal formulas they can escape the law's substance.

The requirement that a state give equal protection to its people can be ineffectual under two sets of circumstances. In the first place, a state obviously can classify its people in many ways without violating the requirement of equal protection; state laws treat children differently from adults, protect women more than men, benefit veterans as a group, tax rich more than poor, promote pupils who pass examinations and hold back those who fail-examples of such permissible differentiation are endless. The equal protection clause means, in plain terms, that equal protection must be given unless there is some legitimate reason for difference. The Supreme Court has made clear that race is not such a legitimate reason, but if some other pretext for classification can be discovered which incidentally classifies Negroes, the Supreme Court is sometimes thought to be precluded from noticing the stratagem, and to be obliged to accept the classification at its face value.

The other escape from the requirement of equal protection is in avoidance of state action. The Fourteenth Amendment is a command to states; in the absence of some such state legislation as the New York Civil Rights Law, a non-governmental group can succeed in discriminating on racial grounds as it sees fit. These two devices-classification on apparently non-racial grounds, and disestablishment of the activity in question so that it appears wholly private-include all the varieties of legal stratagems suggested for escape from the Supreme Court's decision. 'The flaws in plans based on either of them-which will, I think, ultimately bring them to nothing-are the unwillingness of the Court to be duped by unconvincing appearances, and the unwillingness of the people in any state to give up public education. Race is a subject on which the Court has shown itself sensitive. Judges are willing to see through pretext to substance much more readily where the question is race than when it is, say, local police regulation dressed as federal taxation. ${ }^{31}$

One device, much discussed, is the gerrymander. Classification by residential location is a perfectly acceptable means of allotting children to schools, and where many Negro children live in one neighborhood there are bound to be many Negro children in the nearest school, regardless of the state concerned. A school district can be laid out with this in mind, and so achieve a certain amount of racial classification. But the Supreme Court has made clear the constitutional impossibility of legal restriction of any race to a specified neighborhood, ${ }^{32}$ and sooner or later this will defeat even an ingenious plan of racial districting. People will move to get for their children the schooling they desire. Furthermore gerrymandering which pro-

${ }^{31}$ Compare Guinn v. United States, 238 U.S. 347 (1915) in which a "grandfather clause" which had the effect of excluding Negroes from the franchise though not so stated in terms was held invalid, with the case of United States v. Kahriger, 345 U.S. 22 (1953) in which the Supreme Court upheld a federal excise tax on the business of accepting wagers, despite somewhat persuasive arguments that the Congress had made a specious use of the power to tax in order to penalize gambling, an activity prop. erly within the sole cognizance of the several states.

${ }^{32}$ Shelley v. Kraemer, 334 U.S. I (I948). 
gresses to the point of clear defiance of the Supreme Court's judgment is in danger of defeat as a transparent pretext.

Louisiana, during the summer of I954, pressed the theory of permissible classification to a remarkable point by adopting a statute and proposing a state constitutional amendment, both of which undertook to separate white and colored children in public elementary and secondary schools ${ }^{33}$

... in the exercise of the State police power to promote and protect public health, morals, better education and the peace and good order in the state and not because of race.

This appears to be a legislative declaration that the expected difficulties of mixed schools make racial segregation necessary after all!

Not all refusals to delay the end of segregation can be condemned as disingenuous. During a transition period there may well be legitimate educational reasons for gradual desegregation-for the temporary continuation of some Negroes in separate schools. The reason for this arises from sins of the past. In some places the schools for Negroes, one confesses with distress, have been decidedly below the educational standard of white schools. A conscientious school administrator, earnestly devoted to the policy of the Supreme Court's decision and eager to give it full force at the earliest possible moment, may still see that to put some, say, high school sophomores whose preparation is deficient into a class substantially beyond their educational grade is neither kind nor educationally sound. But here again, while classification for genuine educational reasons is permissible, it may not be used as a pretext to continue segregated schools after difference in standards of learning has been adjusted. As the federal courts were able to judge of the equivalence in fact of Negro and white schools when the rule was equal but separate, so they will be able to decide when genuinely educational reasons have ceased to justify continued separateness. $^{34}$

The device of eliminating state action, making all the one-time public schools private and therefore beyond the reach of the Fourteenth Amendment, has progressed in South Carolina to approval by the voters, in November 1952, of a state constitutional amendment, authorizing the legislature to discontinue public schools. ${ }^{35}$ Mississippi is submitting a similar amendment to the voters on December $2 x$, $1954^{35^{a}}$ Governor Talmadge of Georgia has sponsored a state constitutional amendment to

${ }^{33} \mathrm{La}$. Acts 1954, Nos. 555 and 752. The constitutional amendment was approved by the voters in November 1954. See N.Y. Times, Nov. 4, 1954, p. 31, col. I.

34 One suggestion, which seems never to have reached the point of legislation, is the proposal that compulsory desegregation be opposed by the partial means of dividing the schools in the objecting states into schools for boys and schools for girls, thereby eliminating one feature of mixed education which has from time to time evoked criticism. This plan would not, however, achieve the end of preventing all racial association in social equality.

${ }^{35}$ Acts and Joint Resolutions, South Carolina, 1952, No. 902, p. 2223, proposing the repeal of the free public school requirement of South Carolina Constirution, Art. XI, \$5. This amendment under Art. XVI, $\S \mathrm{I}$, to be effective required further action of the General Assembly. It was so ratified on March 19, 1954.

ssz See Southern School News, Oct. 1954, p. 9; N.Y. Times, Sept. 8, 1954, p. 35, col. 3; id., Sept. ro, 1954 , p. 2I, col. 1 . 
be voted on in November $1954,{ }^{36}$ authorizing the General Assembly to "provide for grants of state, county or municipal funds to citizens of the state for educational purposes, in discharge of all obligation of the state to provide adequate education for it [s] citizens." ${ }^{37}$ In no one of these three states is the amendment selfexecuting. The state legislatures are authorized but not required to disestablish their public schools.

One may, to be sure, expect more private schools in the South as a result of the Supreme Court's decision. Wherever the public schools are unsatisfactory to any substantial part of the population for any reason-religious, educational, or othernon-governmental schools have an increased patronage. Furthermore, some public aid to or regulation of a private organization is compatible with sufficient privateness to escape the effect of the Fourteenth Amendment. New York gave land and entrusted the power of eminent domain to Stuyvesant Town Corporation, but its conduct did not seem to a majority of the New York Court of Appeals to amount to state action. ${ }^{38}$ Religious schools are accepted as satisfying the New York requirement of compulsory attendance only if their instruction is at least substantially equal to that given in the public schools, ${ }^{39}$ but they escape the effect of the $\mathrm{McC}$ Collum decision ${ }^{40}$ by reason of their nongovernmental character. The small degree of governmental influence on parochial schools arising out of this requirement of the New York Education Law is not sufficient to make their conduct "state action." The State of New York at a substantial cost fitted a building for classroom use at Canisius College in Buffalo during the great demand for college instruction after the end of the war in $1945,{ }^{41}$ but one does not suppose that that Jesuit institution thereby became subject to the federal constitutional restriction that the Supreme Court applied to the public schools of Champaign, Illinois.

It is theoretically possible, then, for a state which feels strongly enough about the Supreme Court's desegregation decision to abandon public education entirely, so escaping the effect of the Fourteenth Amendment, while still giving some support to private schools or to school children. A state might convey all its school properties to non-governmental corporations, or to individuals, might repeal its compulsory education laws, and merely offer money scholarships to any child, Negro or white, who chose to attend school. But the difficulties are great. ${ }^{42}$ In the first

${ }^{30}$ N.Y. Times, Sept. 5, 1954, p. 36 , col. 6 . This amendment was approved by the voters. N.Y. Times, Nov. 4, x954, p. 31, col. I.

${ }^{37}$ See House Resolution No. 225, Resolution Act No. 156, approved by Governor Talmadge, Dec. II, 1953; see also N.Y. Times, Sept. 14, 1954, p. 23, col. 1 .

${ }^{38}$ Dorsey v. Stuyvesant Town Corp., 299 N.Y. 512, 87 N.E.2d 541 (1949), cert. denied, 339 U.S. 98I (r950).

${ }^{39}$ N.Y. EDUC. LAW $\$ 3204$.

${ }^{10}$ Illinois ex rel. McCollum v. Board of Education, 333 U.S. 203 (1948). The Supreme Court in this case held that the Fourteenth Amendment was violated by the state of Illinois when it permitted religious instruction in a public school classrcom, thereby putting some constraint on a dissenter to avail himself of an excuse to leave the room.

"1 See Bull v. Stichman, 189 Misc. 587, 72 N.Y.S.2d 488 (Sup. Ct. 1947), aff'd, 273 App. Div. 311, 78 N.Y.S.2d 279 (3d Dep't 1948), affd, 298 N.Y. 516, 80 N.E.2d 661 (1948).

\$2 See Lenoir and Lenoir, Compulsory Legal Segregation in the Public Schools, with Special Reference to Gcorgia, 5 Mercer L. Rev. 21 I (1954); Nicholson, The Legal Standing of the South's Scliool Resistance Proposals, 7 S.C.L.Q. I (1954). 
place, the modern South is progressive, growing in wealth, proud of its culture and its high civilization, peopled with kindly and educated Americans. Faced with the prospect of abandoning public education, even when this is proposed because of emotions and customs rooted deep in the past, the people of any southern state will hesitate, and I think, refuse. For the public school, too, is rooted deep in our emotions and our customs. The one-room schoolhouse of our fathers, and the acres-wide consolidated high of our sons, both have been our pride too long to give up. We have heard from too many graduation day platforms that in our country learning is free to everybody, and that the first charge on our means is the support of public education, to be willing to turn away from all this because of what the Supreme Court has told us.

The same pride will, I think, keep any significant numbers of us from trying by elaborate pretense to conceal actual publicness in our schools. Clandestine public education is out of character; the people of no state seem likely to welcome it. Nor would it avail. The device has been tried in the closely related business of elections. When in Texas the members of the Jaybird Association contended that they were purely a private political group having no connection with the state and so entitled on racial or any other grounds to exclude any people they pleased from their polls, the Supreme Court overrode them..$^{43}$

State laws and semi-public controls prejudicial to the Negro race have little viability in the courts. No matter how syllogistically perfect the reasoning by which the policy of the Thirteenth, Fourteenth and Fifteenth Amendments is avoided, the strong policy remains. "Equal but separate" was an ingenious device that worked for fifty-eight years, but the fundamental reason for its final breakdown was stated in Harlan's dissent in the Plessy case:44

I am of opinion that the statute ... is inconsistent with the personal liberty of citizens, white and black .... and hostile to both the spirit and letter of the Constitution of the United States. If laws of like character should be enacted in the several States of the Union, the effect would be in the highest degree mischievous. Slavery as an institution tolerated by law would, it is true, have disappeared from our country, but there would remain a power in the States, by sinister legislation, to interfere with the full enjoyment of the blessings of freedom; to regulate civil rights, common to all citizens, upon the basis of race; and to place in a condition of legal inferiority a large body of American citizens, now constituting a part of the political community called the People of the United States, for whom, and by whom through representatives, our government is administered.

He could have been writing of some school laws.

There will be delays and devices for a while, man being what he is. But by and by it will be self-evident that, so far as concerns their schoolhouses, all children are created equal.

\footnotetext{
13 Terry v. Adams, 345 U.S. $46 \mathrm{I}$ (1953).
}

${ }^{4} \mathrm{r} 63$ U.S. 537 at $563-56_{4}$ (1896). 